\title{
The Effect of Organic Fertilisers on the Floristic Composition of Grassland, Herbage Yield and Quality
}

\author{
Marie Mrázková *, Hana Bilošová, Oldřich Látal and Jan Pozdíšek \\ Agrovýzkum Rapotín s.r.o.., Výzkumníků 267, 788 13, Vikýřovice, Czech Republic; vuchs@vuchs.cz \\ * Correspondence: marie.mrazkova@vuchs.cz; Tel.: +420-583-382-158
}

\begin{abstract}
The aim of this study was to assess the effects of organic fertilisers (cow manure + dung water; cattle slurry) applied in different annual doses of nitrogen (54 kg ha-1; $\left.84 \mathrm{~kg} \mathrm{ha}^{-1} ; 120 \mathrm{~kg} \mathrm{ha}^{-1}\right)$ according to 3 different intensities of grassland utilisation (extensive -2 cuts per year, medium intensive -3 cuts per year, intensive -4 cuts per year) on percentage of plant functional groups (grasses, legumes, forbs), dry matter yield, and forage quality. The study was performed as a smallplot trial over 7 years on moderately moist grassland in the Czech Republic. The proportion of legumes was significantly higher in the fertilisation treatments with cow manure + dung-water combined with medium intensive utilisation and intensive utilisation $(10.2 \%$ and $10.3 \%$, respectively). Fertilisation significantly increased dry matter yields by $51.9 \%$ (cow manure + dung water) and 56\% (cattle slurry) compared to unfertilised controls $\left(4.81 \mathrm{t} \mathrm{ha}^{-1}\right)$. Grasslands fertilised with cattle slurry showed significantly higher concentration of crude protein $\left(142.9 \mathrm{~g} \mathrm{~kg}^{-1}\right)$ than unfertilised (126.4 $\left.\mathrm{g} \mathrm{kg}^{-1}\right)$. Extensive grassland utilisation significantly increased crude fibre concentration (up to $282.1 \mathrm{~g} \mathrm{~kg}^{-1}$ ), and decreased the energy value (up to $4.68 \mathrm{MJ} \mathrm{kg}^{-1}$ of NEL). Organic matter digestibility was negatively influenced by extensive grassland utilisation $(61.0 \%, 65.42 \%$ and $67.44 \%$ for the extensive, medium intensive and intensive utilisation, respectively). Our findings suggest that medium intensive and intensive grassland utilisation using organic fertilisation which correspond to annual doses of nitrogen of $84 \mathrm{~kg} \mathrm{ha}^{-1}$ and $120 \mathrm{~kg} \mathrm{ha}^{-1}$, are the most suitable for animal nutrition.
\end{abstract}

Keywords: permanent grassland; manure; cattle slurry; fertilisation, functional groups

\section{Introduction}

Permanent grasslands are an important part of the landscape in all European countries. They formed and have evolved under the influence of abiotic and biotic ecological environmental factors together with the overwhelming impact of the anthropogenic factor. Their importance consists in the ability to conserve biodiversity, reduce environmental pollution, including nitrogen oxide and sulfur in the air and prevent soil erosion. They are also an important source of forage for a large group of ruminants but only if improvement measures are provided, along with rational use [1].

It is necessary to assess grassland yield and quality in relation to changes in floristic composition [2]. Plant composition and species richness of permanent grasslands are determined by management practices and site characteristics such as topography, water and nutrient availability, and light 
conditions [3-5]. As a result, great variability is seen in floristic composition of the vegetation and hence the productivity and quality of forage produced from these categories of agricultural land [6].

The productive potential and quality of permanent grasslands can be increased by different fertilisation regimes and types of mineral/organic fertilisers. A typical characteristic of fertilisers is that they affect (directly and indirectly) the growth and development of plants [7]. Freely available chemical fertilisers over the past half-century resulted in a period in which efficient nutrient recycling was not prioritized. However, the emphasis on organic fertilisers as a nutrient resource has been reestablished following recent increases in fertiliser prices, more focus on manure management within the European Union (EU) and national environmental policies [8].

Organic agriculture relies on ecosystem management and ecological processes rather than on the external flow of agricultural inputs [9]. Synthetic inputs are replaced with site-specific management practices to balance input and output nutrients to ensure short-term productivity and long-term sustainability. Hence, organic fertilisers are the irreplaceable foundation for rational agriculture. If applied rationally to grasslands, they can entirely replace mineral fertilisers. In addition, organic fertilisers support soil fertility and have other positive effects [10]. Cattle slurry, in particular, is a commonly used fertiliser in many countries and its effects on grassland have been studied $[11,12]$.

In the Czech Republic, the systematic use of organic fertilisers in permanent grasslands is not common because of their preferred application to intensive arable crops. However, their importance is progressively increasing mainly in connection with the development of the organic sector which induces a spatial decoupling of livestock and crop production. Existing methodological recommendations for application of organic fertilisers in the Czech Republic do not take into account a number of key criteria such as, type of fertiliser and recommended dose in relation to type of grassland, altitude and time of application. The long-term experience of other countries particularly Austria is used in this process. Experimental research is essential to extrapolate this knowledge to local Czech conditions.

The objective of this study was to evaluate how the floristic composition, forage yield and permanent grassland quality are influenced by different regimes of organic fertiliser application (cow manure + dung water; cattle slurry) on the basis of the experimental research conducted in the Czech Republic.

\section{Materials and Methods}

\subsection{Study Site}

A long-term small plot experiment (one plot size: $12.5 \mathrm{~m}^{2}$ ) in completely randomised blocks with four replicates was investigated during 2005-2011 on permanent grassland in the locality of Rapotín $\left(50^{\circ} 00^{\prime} 32^{\prime \prime} \mathrm{N}\right.$ and $\left.17^{\circ} 00^{\prime} 83^{\prime \prime} \mathrm{E}\right)$. The experimental site is situated at $390 \mathrm{~m}$ above sea level on the east decline (with 5.1-6.2 ${ }^{\circ}$ declination) in a moderately warm region without temperature extremes. Average annual temperature is $7.7^{\circ} \mathrm{C}$ and annual precipitation $693 \mathrm{~mm}$. Further meteorological data from the Šumperk Meteorological Station are given in Table 1. The soil is sandy-loam, Haplic Cambisol with horizons Am-Bv-Bv/Cc-Cc (classification system according [13]).

Table 2 shows agro-chemical parameters of soil horizons determined in spring 2005. The vegetation of the experimental pasture was classified as Cynosurion with some elements of 
Arrhenatherion [14]. Before the experiment setup, the grassland had been used for cattle grazing for over 30 years.

Table 1. Rainfall and temperature data for experimental fields during the study years.

\begin{tabular}{|c|c|c|c|c|c|c|c|c|c|c|c|c|c|c|}
\hline \multirow{3}{*}{ Year } & \multicolumn{12}{|c|}{ Months } & \multirow{3}{*}{ Average } & \multirow{3}{*}{ Deviation $^{1}$} \\
\hline & Jan & Feb & Mar & Apr & May & Jun & Jul & Aug & Sep & Oct & Nov & Dec & & \\
\hline & \multicolumn{12}{|c|}{ Daily average temperature $\left[{ }^{\circ} \mathrm{C}\right]$} & & \\
\hline 2005 & -1.3 & -4.5 & -0.7 & 8.9 & 12.7 & 15.6 & 18.3 & 15.7 & 13.4 & 4.9 & 3.1 & -1.7 & 7.03 & -0.17 \\
\hline 2006 & -8.4 & -2.6 & -1.8 & 9.3 & 11.2 & 15.8 & 19.3 & 14.2 & 12.6 & 7.8 & 4.9 & 1.6 & 6.99 & -0.21 \\
\hline 2007 & 2.4 & 1.8 & 3.3 & 6.9 & 12.9 & 16.8 & 17.0 & 15.8 & 9.5 & 6.3 & 1.0 & -2.0 & 7.64 & 0.44 \\
\hline 2008 & 0.3 & 0.5 & 1.4 & 6.5 & 11.7 & 16.1 & 16.7 & 15.0 & 10.5 & 7.0 & 4.7 & 0.5 & 7.58 & 0.38 \\
\hline 2009 & -5.3 & -1.5 & 2.3 & 8.5 & 11.4 & 14.2 & 16.8 & 16.0 & 12.6 & 6.1 & 4.0 & -1.4 & 6.98 & -0.23 \\
\hline 2010 & -6.2 & -2.6 & 0.9 & 6.2 & 11.4 & 16.3 & 18.9 & 16.0 & 10.1 & 4.4 & 5.4 & -5.8 & 6.25 & -0.95 \\
\hline \multirow[t]{2}{*}{2011} & -2.9 & -3.8 & 3.0 & 10.5 & 12.8 & 17.5 & 17.0 & 18.1 & 14.2 & 7.8 & 2.3 & 1.1 & 8.13 & 0.93 \\
\hline & \multicolumn{12}{|c|}{ Months } & \multirow{3}{*}{ Total } & \multirow{3}{*}{ Deviation $^{1}$} \\
\hline Year & Jan & Feb & Mar & Apr & May & Jun & Jul & Aug & Sep & Oct & Nov & Dec & & \\
\hline \multicolumn{13}{|c|}{ Precipitation [mm] } & & \\
\hline 2005 & 90.0 & 45.0 & 27.5 & 23.5 & 76.0 & 50.0 & 78.0 & 69.0 & 19.0 & 56.0 & 120.0 & 74.6 & 728.6 & 35.6 \\
\hline 2006 & 36.1 & 63.7 & 62.7 & 62.2 & 84.7 & 89.2 & 41.3 & 125.3 & 22.9 & 31.3 & 73.7 & 32.5 & 725.6 & 32.6 \\
\hline 2007 & 85.6 & 47.2 & 40.1 & 4.0 & 66.4 & 61.5 & 86.6 & 68.3 & 67.9 & 35.9 & 67.0 & 39.9 & 670.4 & -22.6 \\
\hline 2008 & 69.4 & 14.3 & 90.9 & 34.2 & 71.1 & 92.9 & 96.4 & 78.3 & 18.6 & 31.0 & 44.3 & 19.8 & 661.2 & -31.8 \\
\hline 2009 & 37.3 & 56.3 & 70.3 & 16.2 & 66.9 & 88.7 & 120.6 & 35.1 & 10.6 & 78.1 & 41.2 & 68.1 & 689.4 & -3.6 \\
\hline 2010 & 62.6 & 45.3 & 28.2 & 25.8 & 176.6 & 68.5 & 135.1 & 128.9 & 93.1 & 5.5 & 73.9 & 54.7 & 898.2 & 205.2 \\
\hline 2011 & 39.8 & 7.7 & 25.0 & 29.5 & 52.0 & 94.0 & 154.0 & 98.1 & 36.1 & 37.2 & 2.0 & 84.0 & 659.4 & -33.6 \\
\hline
\end{tabular}

${ }^{1}$ Deviation from long-term annual average [1961-1990]. Šumperk Meteorological Station.

Table 2. Soil agro-chemical parameters of soil horizons determined in spring 2005.

\begin{tabular}{|c|c|c|c|c|c|c|c|c|}
\hline Horizon ${ }^{1}$ & pHксl & $\begin{array}{l}\text { Cox } \\
{[\%]}\end{array}$ & $\begin{array}{l}\text { Ratio } \\
\mathrm{C}: \mathrm{N}\end{array}$ & $\begin{array}{c}\mathbf{N}_{\text {tot }} \\
{\left[\mathrm{g} \mathrm{kg}^{-1}\right]}\end{array}$ & $\begin{array}{c}\mathbf{P} \\
{\left[\mathrm{mg} \mathrm{kg}^{-1}\right]}\end{array}$ & $\begin{array}{c}\mathbf{K} \\
{\left[\mathrm{mg} \mathrm{kg}^{-1}\right]}\end{array}$ & $\begin{array}{c}\text { Ca } \\
{\left[\mathrm{mg} \mathrm{kg}^{-1}\right]}\end{array}$ & $\begin{array}{c}\mathbf{M g} \\
{\left[\mathrm{mg} \mathrm{kg}^{-1}\right]}\end{array}$ \\
\hline Am & 4.63 & 1.34 & 10.0 & 1.34 & 53 & 109 & 1799 & 124 \\
\hline $\mathrm{Bv}$ & 4.60 & 0.73 & 9.5 & 0.77 & 78 & 62 & 1442 & 97 \\
\hline $\mathrm{Bv} / \mathrm{Cc}$ & 4.41 & 0.33 & 8.4 & 0.39 & 27 & 53 & 1753 & 131 \\
\hline $\mathrm{Cc}$ & 4.44 & 0.19 & 10.5 & 0.18 & 29 & 45 & 1875 & 166 \\
\hline
\end{tabular}

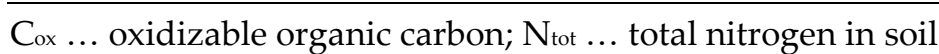

${ }^{1}$ Classification system of soil horizons according [13].

\subsection{Treatments}


Two types of organic fertilisers were applied during 2005-2011: (M) combination of cow manure + dung water, and (S) cattle slurry. Organic fertilisers were used in annual doses of nitrogen: $54 \mathrm{~kg}$ $\mathrm{ha}^{-1} ; 84 \mathrm{~kg} \mathrm{ha}^{-1} ; 120 \mathrm{~kg} \mathrm{ha}^{-1}$, which approx. corresponded to $0.9 \mathrm{LU}^{\mathrm{k}} \mathrm{h}^{-1}$ (LU = livestock unit), 1.4 LU ha $^{-1}$ and $2.0 \mathrm{LU} \mathrm{ha}^{-1}$. The first 50\% dose of the cattle slurry (diluted with water in a ratio 1:3) was applied early in spring and the second 50\% after the first cut. Cow manure was applied in autumn, dung water after the first cut. The fertilisers were analysed for nutrient content before application which was annually during 2005-2011.

The plots were cut 2-4 times per year depending on the given dose of fertiliser. Unfertilised plots (F-0) with three types of utilisation were also observed as the control treatments: two- (extensive), three- (medium intensive) and four- (intensive) cuts per year. Treatments as fertilisation and cutting regime are shown in Table 3.

Table 3. Description of treatments with different grassland management.

\begin{tabular}{|c|c|c|c|c|c|c|c|}
\hline & & Annual dose & & & & & \\
\hline Treatment & Fertilisation & of nitrogen & Application & $1^{\text {st }}$ cut & $2^{\text {nd }} \mathrm{cut}$ & $3^{\text {rd }}$ cut & $4^{\text {th }}$ cut \\
\hline F-0-ext & nil-fertilisation & $0 \mathrm{~kg} \mathrm{ha}^{-1}$ & --- & June 15 & Sept. 30 & - & - \\
\hline F-0-med.int. & nil-fertilisation & $0 \mathrm{~kg} \mathrm{ha}^{-1}$ & --- & May 30 & July 30 & Sept. 30 & - \\
\hline F-0-int. & nil-fertilisation & $0 \mathrm{~kg} \mathrm{ha}^{-1}$ & --- & May 15 & June 30 & Aug. 15 & Sept. 15 \\
\hline M-0.9-ext. & $\begin{array}{l}\text { cow manure } \\
\text { + dung water }\end{array}$ & $54 \mathrm{~kg} \mathrm{ha}^{-1}$ & $\begin{array}{l}\text { cow manure - in autumn; } \\
\text { dung water - after the } 1^{\text {st }} \text { cut }\end{array}$ & June 15 & Sept. 30 & - & - \\
\hline M-1.4-med.int. & $\begin{array}{l}\text { cow manure } \\
+ \text { dung water }\end{array}$ & 84 kg ha-1 & $\begin{array}{l}\text { cow manure - in autumn; } \\
\text { dung water - after the } 1^{\text {st }} \text { cut }\end{array}$ & May 30 & July 30 & Sept. 30 & - \\
\hline M-2.0-int. & $\begin{array}{l}\text { cow manure } \\
\text { + dung water }\end{array}$ & $120 \mathrm{~kg} \mathrm{ha}^{-1}$ & $\begin{array}{l}\text { cow manure - in autumn; } \\
\text { dung water - after the } 1^{\text {st }} \text { cut }\end{array}$ & May 15 & June 30 & Aug. 15 & Sept. 15 \\
\hline S-0.9-ext. & cattle slurry & $54 \mathrm{~kg} \mathrm{ha}^{-1}$ & $\begin{array}{l}50 \% \text { of dose - in spring, } \\
50 \% \text { of dose - after the } 1^{\text {st }} \text { cut }\end{array}$ & June 15 & Sept. 30 & - & - \\
\hline S-1.4-med.int. & cattle slurry & $84 \mathrm{~kg} \mathrm{ha}^{-1}$ & $\begin{array}{l}50 \% \text { of dose - in spring, } \\
50 \% \text { of dose - after the } 1^{\text {st }} \text { cut }\end{array}$ & May 30 & July 30 & Sept. 30 & - \\
\hline S-2.0-int. & cattle slurry & $120 \mathrm{~kg} \mathrm{ha}^{-1}$ & $\begin{array}{l}50 \% \text { of dose - in spring, } \\
50 \% \text { of dose - after the } 1^{\text {st }} \text { cut }\end{array}$ & May 15 & June 30 & Aug. 15 & Sept. 15 \\
\hline
\end{tabular}

\subsection{Evaluated Parameters}


The proportion of three functional groups (grasses, legumes, forbs) was visually estimated directly in percentages in each plot in May (before the first harvest) each year of the study. Cover estimates ranged from 0.5 to $100 \%$.

Dry matter (DM) annual yield and quality of grasslands was also measured. In each plot, the sward was mown by machine leaving a stubble height of approximately $5 \mathrm{~cm}$. The harvested biomass was immediately weighed and the percentage of DM determined in the laboratory after $48 \mathrm{~h}$ of drying at $65^{\circ} \mathrm{C}$. It was then expressed as DM yield in $t \mathrm{ha}^{-1}$. Nutrients in samples collected during the vegetation seasons 2005-2009, depending on the term of the cut, were analysed according to Czech State Standard 467092 (Testing methods of feeding-stuffs). Crude protein (CP) was determined by the Kjeldahl procedure using the device Kjeltec Auto Distillation 2200 and ether extract (EE) by the Soxhlet method. The Fibertec System 2023 FiberCap (FOSS Comp.) was used to analyse crude fibre (CF). Ash (A) content was measured gravimetrically by igniting samples in a muffle furnace at $450^{\circ} \mathrm{C}$ for $4 \mathrm{~h}$. The concentration of nitrogen-free extract (NFE) was calculated according to the formula: NFE $\left(\mathrm{g} \mathrm{kg}^{-1} \mathrm{DM}\right)=1000-(\mathrm{CP}+\mathrm{EE}+\mathrm{CF}+\mathrm{A})$. The in-vitro organic matter digestibility (OMD) was determined by the Tilley and Terry [15) modified according to Resch [16]. The energy value (ME metabolisable energy; NEL - net energy of lactation) was predicted using the equations officially accepted in the Czech and Slovak Republic, which corresponds with the system INRA [17].

\subsection{Statistical Analyses}

Analysis of variance (ANOVA) followed by Tukey HSD test $(P<0.05)$ was used for the statistical data analysis by means of the software Statistica v. 10.

\section{Results and Discussion}

\subsection{Floristic Composition}

Data for the proportion of functional groups (grasses, legumes, forbs) are given as percentage in Table 4. We found that grassland management had an effect on floristic composition and some of the differences were statistically significant $(P<0.05)$. The mean proportion of grasses was positively influenced by cattle slurry (53.4\%), compared to fertilisation with cow manure + dung water $(48.8 \%)$, and control (42.9\%). This percentage increased significantly with decrease in cutting frequency and reduction in fertiliser doses. In contrast, the unfertilised treatments showed significantly higher proportion of forbs (53.3\%) in the means for years, and this proportion significantly increased with increasing intensity of utilisation (from $39.9 \%$ in the extensive utilisation to $51.5 \%$ in the intensive utilisation). The mean proportion of legumes was significantly higher in the treatments with application of cow manure + dung-water combined with medium intensive utilisation and intensive grassland utilisation (10.2\% and $10.3 \%$, respectively).

Comparing our results with other studies, [18] showed the effects of organic fertilisers on the floristic composition of permanent grassland and they found that the sward proportion of grasses rose with increasing rates of fertilisation. With manure application, the proportion of grasses was dominant in the first year, then diminished. The forb and legume proportions increased which corresponds to our results.

In contrast, [19] found that the percentage of legumes in grassland increased with greater application rate of swine slurry. The reason for this finding could be that pig slurry supplies more 
phosphorus than does cow slurry (Christie 1987). On average, pig slurry is twice as rich in phosphorous as cattle slurry (Regulation No. 274/1998 of the Ministry of Agriculture) and phosphorus has a positive effect on legume dominance in grasslands as has been reported by $[20,21,22]$.

The long-term application of organic fertilisers resulted in significant changes in sward floristic composition in the studies of [11]) too. [23] investigated the effects of different fertilisation systems (organic and mineral fertilisers) on permanent grasslands and found that fertilisation with slurry increased the proportions of grasses, whereas farmyard manure increased forbs; the proportion of legumes was increased by PK and by fertilisation with slurry plus lime. [24] reported that cattle slurry decreased the proportion of legume species, increased the grass proportion but barely affected the non-leguminous herbs in grasslands.

Differences in findings could be caused by different soil-climatic conditions and types of grasslands of experimental study sites and also by treatment differences (e.g. doses of manures, modes of application etc.).

\subsection{Dry Matter Yields}

Data for dry matter (DM) yields of grasslands by management, as well as the significance of differences are given in Table 5. Significantly higher DM yields were found for the fertilisation treatments. Cow manure + dung water increased DM yield by $51.9 \%$ and cattle slurry by $56.0 \%$, compared to unfertilised control $\left(4.81 \mathrm{t} \mathrm{ha}^{-1}\right)$. Differences between the types of organic fertilisers used (cattle slurry vs. cow manure) on DM yield were not significant in our study. However, we found a slightly higher DM yield in the slurry treatment $\left(7.51 \mathrm{tha}^{-1}\right)$ than in the fertilisation treatment with cow manure + dung water $\left(7.31 \mathrm{t} \mathrm{ha}^{-1}\right)$.

We also found an effect of intensity of utilisation in our study. In the grasslands utilised extensively (two cuts per year) fertilised with the lowest doses of organic manures, we found a significantly lower mean DM yield $\left(6.14 \mathrm{t} \mathrm{ha}^{-1}\right)$ in contrast to grasslands with medium intensive and intensive utilisation (6.82 $\mathrm{t} \mathrm{ha}^{-1}$ and $6.68 \mathrm{t} \mathrm{ha}^{-1}$, for three and four cuts per year, respectively). This finding is not in agreement with [25] or [26], who documented that the treatment of 4 cuts is unfavourable in terms of production, which was explained in relation to the phenological development of the swards. Our results demonstrated that DM yields were significantly influenced by level of organic fertilisation. This is in accord with [27,19,10,28]. [29] who investigated via the same experiment at two different localities in the Czech Republic (Jevíčko, Vysoké nad Jizerou) had similar results. In contrast, [30]) found that the addition of organic manure produced no increment in DM yields, which was probably caused by significant changes in the floristic composition.

Table 4. Floristic composition of grasslands (\% of functional groups) over treatments and years.

\begin{tabular}{llll}
\hline Functional group & Grasses & Legumes & Forbs \\
\hline Treatments $^{1}$ & & & \\
\hline
\end{tabular}




$\begin{array}{llcl}\text { F-0-ext. } & 49.0^{\mathrm{ae}} & 1.9 & 49.1 \\ \text { F-0-med.int. } & 40.5^{\mathrm{b}} & 4.5 & 54.9 \\ \text { F-0-int. } & 39.2^{\mathrm{b}} & 4.2 & 55.9 \\ \text { M-0.9-ext. } & 59.6^{\mathrm{c}} & 4.1 & 36.2 \\ \text { M-1.4-med.int. } & 45.3^{\mathrm{ad}} & 10.2 & 44.5 \\ \text { M-2.0-int. } & 41.8^{\mathrm{bd}} & 10.3 & 47.5 \\ \text { S-0.9-ext. } & 63.6^{\mathrm{c}} & 1.7 & 34.5 \\ \text { S-1.4-med.int. } & 53.2^{\mathrm{e}} & 3.9 & 42.6 \\ \text { S-2.0-int. } & 43.5^{\mathrm{bd}} & 4.7 & 50.1\end{array}$

\section{Means for fertilisation type}

\begin{tabular}{llll}
\hline (F) nil-fertilisation & $42.9^{\mathrm{a}}$ & $3.5^{\mathrm{a}}$ & $53.3^{\mathrm{a}}$ \\
(M) cow manure + dung water & $48.8^{\mathrm{b}}$ & $8.2^{\mathrm{b}}$ & $42.7^{\mathrm{b}}$ \\
(S) cattle slurry & $53.4^{\mathrm{c}}$ & $3.4^{\mathrm{a}}$ & $42.7^{\mathrm{b}}$ \\
\hline
\end{tabular}

\section{Means for utilisation intensities}

\begin{tabular}{|c|c|c|c|}
\hline (ext.) extensive & $57.4^{\mathrm{a}}$ & $2.6^{\mathrm{a}}$ & $39.9^{a}$ \\
\hline (med. int.) medium intensive & $46.3^{\mathrm{b}}$ & $6.2^{\mathrm{b}}$ & $47.3^{\mathrm{b}}$ \\
\hline (int.) intensive & $41.5^{\mathrm{c}}$ & $6.4^{\mathrm{b}}$ & $51.5^{c}$ \\
\hline \multicolumn{4}{|l|}{ Means for years } \\
\hline 2005 & $51.1^{\mathrm{a}}$ & $14.7^{\mathrm{a}}$ & $34.1^{\mathrm{ab}}$ \\
\hline 2006 & $52.1^{\mathrm{ab}}$ & $11.7^{\mathrm{b}}$ & $35.7^{a}$ \\
\hline 2007 & $68.8^{c}$ & $0.8^{\mathrm{c}}$ & $29.8^{\mathrm{b}}$ \\
\hline 2008 & $56.2^{\mathrm{b}}$ & $0.5^{\mathrm{c}}$ & $43.3^{c}$ \\
\hline 2009 & $32.8^{\mathrm{d}}$ & $0.6^{\mathrm{c}}$ & $66.4^{\mathrm{d}}$ \\
\hline 2010 & $37.0^{\mathrm{e}}$ & $1.5^{\mathrm{c}}$ & $60.8^{\mathrm{e}}$ \\
\hline 2011 & $40.6^{\mathrm{e}}$ & $5.6^{\mathrm{d}}$ & $53.6^{\mathrm{f}}$ \\
\hline Factor & & $P$ value & \\
\hline year & $<0.001$ & $<0.001$ & $<0.001$ \\
\hline fertilisation & $<0.001$ & $<0.001$ & $<0.001$ \\
\hline intensity of utilisation & $<0.001$ & $<0.001$ & $<0.001$ \\
\hline fertilisation*int. of utilisation & 0.011 & 0.073 & 0.076 \\
\hline
\end{tabular}

The values in the same column with different superscript letters are significantly different at $P<0.05$ level for each variable (Tukey's HSD test).

${ }^{1}$ see Table 3

In our study, DM yields were also affected by annual climate. It can be seen from Table 1, April 2007 was characterized by an exceptionally low level of precipitation $(4.0 \mathrm{~mm})$, which negatively affected the spring growth of plants at our study site. This resulted not only in a significant decrease in mean total seasonal DM yield $\left(4.15 \mathrm{t} \mathrm{ha}^{-1}\right)$, but also in a significantly reduced forage quality (113.8 
$\mathrm{g} \mathrm{kg}^{-1} \mathrm{DM}$ of CP; $4.68 \mathrm{MJ} \mathrm{kg}^{-1} \mathrm{DM}$ of NEL) in this year 2007 (Table 5 and Table 6). From Table 4 it is clear that the exceptionally dry year 2007 also had an effect on the floristic composition (significantly higher proposition of grasses to the detriment of forbs), which is in line with [31]. [32] found that the quantity of annual herbage DM yield correlated highly with the amount of precipitation during the March-August period. This finding is also described in relation to climatic conditions by [33].

\subsection{Forage Quality}

Regarding the effect of different grassland management on forage quality (Table 6), we found a significant increase in concentration of $\mathrm{CP}$ with increasing intensity of grassland utilisation up to $152.1 \mathrm{~g} \mathrm{~kg}^{-1} \mathrm{DM}$ in the annual means whereas grasslands fertilised with cattle slurry showed a significantly higher concentration of CP $\left(142.9 \mathrm{~g} \mathrm{~kg}^{-1} \mathrm{DM}\right)$ than unfertilised $\left(126.4 \mathrm{~g} \mathrm{~kg}^{-1} \mathrm{DM}\right)$. Further, we found that the extensive grassland utilisation significantly affected the increase in concentration of CF (up to $282.1 \mathrm{~g} \mathrm{~kg}^{-1} \mathrm{DM}$ ), decrease in concentration of EE (up to $26.4 \mathrm{~g} \mathrm{~kg}^{-1} \mathrm{DM}$ ), and decrease in energy value (up to $8.21 \mathrm{MJ} \mathrm{kg}^{-1} \mathrm{DM}$ of ME; or up to $4.68 \mathrm{MJ} \mathrm{kg}^{-1} \mathrm{DM}$ of NEL). Organic matter digestibility (OMD) was negatively influenced by extensive grassland utilisation $(61.0 \%, 65.42 \%$ and $67.44 \%$ for the extensive, medium intensive and intensive grassland utilisation, respectively).

These results on forage quality are in agreement with [30], who found that the fertilised (including organic fertilisers) swards produced 55-60\% more protein. [34] conducted experiments on the influence of organic fertilisation on content of crude protein, crude fiber, phosphorus and raw ash. The applied fertilisation systems resulted in an increased fodder yield and CP content, compared with the unfertilised control, by $14-29 \%$ on Nardus stricta grassland and by $9-22 \%$ on Agrostis capillaris + Festuca rubra grassland.

Intensive grassland utilisation is usually connected with a decrease in DM yield and simultaneous increase in forage quality [25]. Within our study, we found that higher doses of organic fertilisers (especially cattle slurry) and increasing grassland utilisation had a more significant effect than intensity of utilisation. Our finding could be explained by the fact that cattle slurry provided a source of fast-release nitrogen which could be immediately utilised by the plants for their growth. As [35] have reported, slurries typically contain more inorganic than organic $\mathrm{N}$, whereas most of the inorganic $\mathrm{N}$ in slurries is present as $\mathrm{N}-\mathrm{NH}_{4}{ }^{+}$.

Table 5. Dry matter yields of grasslands at different levels of intensity of utilisation and fertilisation with organic fertilisers.

\begin{tabular}{lc} 
Treatments $^{1}$ & Dry matter yield [t ha- $\left.\mathbf{~}^{-1}\right]$ \\
\hline F-0-ext. & $4.90^{\mathrm{a}}$ \\
F-0-med.int. & $4.93^{\mathrm{a}}$
\end{tabular}


F-0-int.

M-0.9-ext.

$6.75^{\mathrm{b}}$

M-1.4-med.int.

M-2.0-int.

S-0.9-ext.

S-1.4-med.int.

S-2.0-int.

$7.88^{c}$

\section{Means for fertilisation type}

(F) nil-fertilisation

(M) cow manure + dung water

(S) cattle slurry

$7.51^{\mathrm{b}}$

Means for utilisation intensities

\begin{tabular}{ll} 
(ext.) extensive & $6.14^{\mathrm{a}}$ \\
(med. int.) medium intensive & $6.82^{\mathrm{b}}$ \\
(int.) intensive & $6.68^{\mathrm{b}}$ \\
\hline
\end{tabular}

\begin{tabular}{lc} 
Means for years & \\
\hline 2005 & $6.14^{\mathrm{a}}$ \\
2006 & $6.06^{\mathrm{a}}$ \\
2007 & $4.15^{\mathrm{b}}$ \\
2008 & $7.42^{\mathrm{c}}$ \\
2009 & $6.75^{\mathrm{d}}$ \\
2010 & $7.37^{\mathrm{c}}$ \\
2011 & $7.95^{\mathrm{e}}$ \\
\hline Factor & $\boldsymbol{P}$ value \\
\hline year & $<0.001$ \\
fertilisation & $<0.001$ \\
intensity of utilisation & $<0.001$ \\
fertilisation*int. of utilisation & $<0.001$ \\
\hline
\end{tabular}

The values in the same column with different superscript letters are significantly different at $P<0.05$ level (Tukey's HSD test).

${ }^{1}$ see Table 3

Table 6. Forage quality (content of nutrients in dry matter) of grasslands at different levels of intensity of utilisation and fertilisation with organic fertilisers.

\begin{tabular}{lcccccccc}
\hline Traits & CP & CF & EE & A & NFE & OMD & ME & NEL \\
& {$\left[\mathrm{g} \mathrm{kg}^{-1}\right]$} & {$\left[\mathrm{g} \mathrm{kg}^{-1}\right]$} & {$\left[\mathrm{g} \mathrm{kg}^{-1}\right]$} & {$\left[\mathrm{g} \mathrm{kg}^{-1}\right]$} & $\begin{array}{c}{\left[\mathrm{g} \mathrm{kg}^{-1}\right]} \\
{[\%]}\end{array}$ & {$\left[\mathrm{MJ} \mathrm{kg}^{-1}\right]$} & {$\left[\mathrm{MJ} \mathrm{kg}^{-1}\right]$} \\
\hline Treatments & \\
\hline F-0-ext. & 108.9 & 274.9 & 27.8 & 99.8 & 488.5 & 61.37 & 8.34 & 4.78
\end{tabular}




\begin{tabular}{lcccccccc} 
F-0-med.int. & 120.8 & 258.1 & 29.8 & 111.5 & 479.8 & 65.07 & 8.84 & 5.13 \\
F-0-int. & 139.4 & 237.9 & 32.2 & 110.6 & 480.0 & 66.83 & 9.17 & 5.36 \\
M-0.9-ext. & 112.6 & 284.1 & 25.7 & 96.8 & 480.9 & 60.65 & 8.11 & 4.62 \\
M-1.4-med.int. & 130.4 & 249.6 & 31.4 & 106.3 & 482.3 & 65.47 & 8.81 & 5.11 \\
M-2.0-int. & 154.9 & 225.9 & 34.8 & 112.0 & 472.3 & 67.73 & 9.12 & 5.32 \\
S-0.9-ext. & 116.2 & 287.1 & 25.8 & 99.3 & 471.6 & 61.05 & 8.16 & 4.66 \\
S-1.4-med.int. & 135.2 & 253.8 & 31.5 & 108.2 & 471.3 & 65.71 & 8.83 & 5.12 \\
S-2.0-int. & 162.0 & 236.2 & 33.7 & 120.1 & 448.0 & 67.76 & 9.02 & 5.26 \\
\hline
\end{tabular}

\section{Means for fertilisation type}

\begin{tabular}{lllllllll}
\hline (F) nil-fertilisation & $126.4^{\mathrm{a}}$ & 257.0 & 30.4 & 107.3 & 482.8 & 64.42 & 8.78 & 5.09 \\
(M) cow manure + dung water & $137.4^{\mathrm{b}}$ & 253.2 & 31.7 & 105.0 & 478.5 & 64.62 & 8.68 & 5.01 \\
(S) cattle slurry & $142.9^{\mathrm{b}}$ & 259.0 & 31.2 & 109.2 & 463.6 & 64.84 & 8.67 & 5.01 \\
\hline
\end{tabular}

Means for utilisation intensities

\begin{tabular}{|c|c|c|c|c|c|c|c|c|}
\hline (ext.) extensive & $112.6^{\mathrm{a}}$ & $282.1^{\mathrm{a}}$ & $26.4^{\mathrm{a}}$ & 98.6 & 480.3 & $61.02^{\mathrm{a}}$ & $8.21^{\mathrm{a}}$ & $4.68^{\mathrm{a}}$ \\
\hline (med. int.) medium intensive & $128.8^{\mathrm{b}}$ & $253.8^{\mathrm{b}}$ & $30.9^{b}$ & 108.7 & 477.8 & $65.42^{\mathrm{b}}$ & $8.83^{\mathrm{b}}$ & $5.11^{b}$ \\
\hline (int.) intensive & $152.1^{\mathrm{c}}$ & $233.3^{c}$ & $33.6^{c}$ & 114.2 & 466.7 & $67.44^{\mathrm{b}}$ & $9.11^{\mathrm{b}}$ & $5.31^{\mathrm{b}}$ \\
\hline \multicolumn{9}{|l|}{ Means for years } \\
\hline 2005 & $138.4^{\mathrm{ab}}$ & 256.8 & 28.4 & 100.5 & 480.5 & $66.4^{\mathrm{a}}$ & $8.99^{a}$ & $5.24^{\mathrm{a}}$ \\
\hline 2006 & $143.8^{\mathrm{ab}}$ & 251.6 & 33.9 & 102.4 & 474.7 & $66.4^{\mathrm{a}}$ & $9.01^{\mathrm{a}}$ & $5.25^{\mathrm{a}}$ \\
\hline 2007 & $113.8^{c}$ & 269.3 & 31.2 & 112.4 & 478.8 & $62.5^{\mathrm{b}}$ & $8.20^{\mathrm{b}}$ & $4.68^{\mathrm{b}}$ \\
\hline 2008 & $132.3^{\mathrm{a}}$ & 262.4 & 32.2 & 118.8 & 459.1 & $65.5^{\mathrm{ab}}$ & $8.96^{\mathrm{a}}$ & $5.21^{\mathrm{a}}$ \\
\hline 2009 & $149.4^{\mathrm{b}}$ & 242.0 & 29.8 & 101.7 & 481.8 & $65.9^{\mathrm{a}}$ & $8.89^{a}$ & $5.16^{\mathrm{a}}$ \\
\hline Factor & \multicolumn{8}{|c|}{$P$ value } \\
\hline year & $<0.001$ & 0.283 & 0.052 & 0.170 & 0.359 & 0.038 & 0.009 & 0.009 \\
\hline fertilisation & 0.024 & 0.840 & 0.874 & 0.833 & 0.122 & 0.952 & 0.860 & 0.859 \\
\hline intensity of utilisation & $<0.001$ & $<0.001$ & $<0.001$ & 0.089 & 0.283 & $<0.001$ & 0.001 & 0.001 \\
\hline fertilisation*int. of utilisation & 0.822 & 0.931 & 0.702 & 0.938 & 0.844 & 0.992 & 0.995 & 0.995 \\
\hline
\end{tabular}

The values in the same column with different superscript letters are significantly different at $P<0.05$ level for each variable (Tukey's HSD test).

${ }^{1}$ see Table 3

Abbreviations: $\mathrm{CP}=$ crude protein; $\mathrm{CF}=$ crude fibre; $\mathrm{EE}=$ ether extract; $\mathrm{A}=$ ash; $\mathrm{NFE}=$ nitrogen free extract; $\mathrm{OMD}=$ organic matter digestibility; $\mathrm{ME}=$ metabolisable energy; $\mathrm{NEL}=$ net energy of lactation.

\section{Conclusions}

Our results allow us to conclude that extensive grassland utilisation and organic fertiliser application (cattle slurry in particular) significantly increase the proportion of grasses. The application of cow manure + dung water together with intensive and medium intensive grassland utilisation positively influenced the proportion of legumes. DM yields were significantly affected by yearly climate and by organic fertilisation compared to unfertilised controls. Increasing doses of both 
types of organic fertilisers significantly increased DM yields, even though the treatments with higher doses of fertilisers were utilised more intensively.

Appropriate grassland management through the number of cuts and fertilisation enable improvement in floristic composition, and amount and quality of forage. In our study, cattle slurry significantly increased the concentration of crude protein in dry matter compared to unfertilised control. Extensive grassland utilisation significantly affected the increase in concentration of crude fibre, and decrease in energy value as well as organic matter digestibility.

Our findings suggest that medium intensive (three cuts per year) and intensive grassland utilisation (four cuts per year) and fertilisation with organic fertilisers, which correspond to $84 \mathrm{~kg} \mathrm{~N}$ ha $^{-1}$ year ${ }^{-1}$ and $120 \mathrm{~kg} \mathrm{~N}^{-1} \mathrm{year}^{-1}$, are the most suitable management practices from the viewpoint of animal nutrition. There are other relevant environmental factors that could influence these parameters, including climatic conditions, which are different for each locality and vegetation season. For specific sites, it is necessary to take into account the possible environmental risks, which could arise from the use of high doses of organic fertilisers (e.g. decrease in species diversity, leaching of nutrients into ground water).

Author Contributions: Conceptualization, M.M..; methodology, M.M., H.B., O.L. and J.P.; software, M.M.; validation, H.B., O.L. and J.P.; formal analysis, M.M.; investigation, M.M.; resources, M.M.; data curation, M.M., H.B.,O.L. and J.P.; writing - original draft preparation, M.M.; writing-review and editing, H.B., O.L. and J.P.; visualization, M.M.; supervision, H.B. and J.P.; project administration, M.M. and H.B.; funding acquisition, M.M. All authors have read and agreed to the published version of the manuscript.

Funding: This work was supported by the Ministry of Agriculture of the Czech Republic, institutional support MZE-RO1218.

Acknowledgments: The authors would like to thank the laboratory staff, technicians, and all their predecessors for their work on long-term fertiliser experiments.

Conflicts of Interest: The authors declare no conflict of interest.

\section{References}

1. Czembor, E. Effects of organic fertilization on agronomic traits of perennial grass species recommended for conventional and low input farming. Biuletyn Instytutu Hodowli i Aklimatyzacji Roślin. 2013, 270, 85-107.

2. Müller, M.; Hrabě, F.; Chroust, J. Changes in forage quality of pasture sward in course of grazing period. In Kvalita píce z travních porostů, Kohoutek, A.; Pozdíšek, J., Eds, VÚRV, v.v.i., Praha-Ruzyně, 2005, pp. 106-111.

3. Sebastiá, M.T. Role of topography and soils in grassland structuring at the landscape and community scales. Basic and Appl. Ecol. 2004, 5, 331-346. [CrossRef]

4. Tzialla, C.E.; Veresoglou, D.S.; Papakosta, D.; Mamolos, A.P. Changes in soil characteristics and plant species composition along a moisture gradient in a Mediterranean pasture. J. Environ. Manag. 2006, 80, 90-98. [CrossRef ]

5. Wellstein, C.; Otte, A.; Waldhardt, R. Impact of site and management on the diversity of central European mesic grassland. Agric. Ecosyst. Environ. 2007, 122, 203-210. [CrossRef] 
6. Criste, D.; Mihai, G.; Sima, N.; Medrea, I.; Botis, A.; Sima, R. Studies regarding the influence of organic and mineral fertilization on the permanent grassland from Maramures depression - Petrova. Bulletin UASVM Animal Science and Biotechnologies. 2013, 70, 240-243.

7. Pozdíšek, J.; Štýbnarová, M.; Kohoutek, A.; Svozilová, M.; Ržonca, J. Forage quality by animal fertilizer applications and by different grassland management. Grassl. Sci. Eur. 2008, 13, 498-500.

8. Foissy, D.; Vian, J.F.; David, C. Managing nutrient in organic farming system: reliance on livestock production for nutrient management of arable farmland. Organic Agric. 2013, 3, 183-199. [CrossRef] 9. Lalor, S.T.J.; Schröder, J.J.; Lantinga, E.A.; Oenema, O.; Kirwan, L.; Schulte, R.P.O. Nitrogen fertilizer replacement value of cattle slurry in grassland as affected by method and timing of application. J. Environ. Qual. 2011, 40, 362-373. [CrossRef]

10. Samuil, C.; Vintu, V.; Iacob, T.; Saghin, G.H.; Trofin, A. Management of permanent grasslands in North-Eastern Romania. Grassl. Sci. Eur. 2009, 14, 234-237.

11. Liu, W.; Zhu, Y.G.; Christie, P.; Laidlaw, A.S. Floristic composition, production and nutrient status of an originally Lolium perenne-dominant cut grass sward receiving long-term manure applications. Plant Soil. 2010, 326, 355-367. [CrossRef]

12. Duffková, R.; Libichová, H. Effects of cattle slurry application on plant species composition of moderately moist Arrhenatherion grassland. Plant Soil Environ. 2013, 59, 485-491.

13. IUSS Working Group WRB. World reference base for soil resources 2006. World Soil Resources Reports, 2006, No. 103, FAO : Rome. 145 pp.

14. Moravec, J.; Balátová-Tuláčková, E.; Blažková, D.; Hadač, E.; Hejný, S.; Husák, Š.; Jeník, J.; Kolbek, J.; Krahulec, F.; Kropáč, Z.; Neuhäusl, R.; Rybníček, K.; Řehořek, V.; Vicherek, J. Rostlinná společenstva České republiky a jejich ohrožení [Red list of plant communities of the Czech Republic and their endangerment]. 1995, 2nd Ed, Litoměřice. 206 pp.

15. Tilley, J.M.A.; Terry, R.A. A two stage technique for the in vitro digestion of forage crops. Grass Forage Sci. 1963, 18, 104-111.

16. Resch, R. In vitro - Verdaulichkeitsuntersuchung nach Tilley und Terry, 1963. [In vitro determination of organic matter digestibility by Tilley and Terry, 1963.] In Bericht über die Tagung der ALVA Fachgruppe Versuchswesen. 1991, Innsbruck 22-23. Mai 1991.

17. Jarrige, R. Ruminant nutrition. 1989, Paris-London-Rome : John Libbey Eurotext.

18. Čunderlík, J.; Kizeková, M. The application of mineral and organic fertilizers and its impact on the quality and production of herbage at semi-natural grassland. In Kováčiková, Z.; Vargová, V.; Jendrišáková, S., Eds, Ecosystems and their functions. 2012, Banská Bystrica, Plant Production Research Centre Pieštany.

19. Sei-Hyung, Y.; Young-Chul, L.; Jong-Geun, K.; Eui-Soo, J. The study on the application level of swine slurry in grassland pasture. J. Korean Soc. Grassl. Sci. 2006, 26, 63-68.

20. Skládanka, J.; Hrabě, F. Effect of fertilization and cutting frequency on floristic composition, diversity and grassland quality. Agriculture (Pol'nohospodárstvo). 2008, 54, 1-8.

21. Veselá, M.; Mrkvička, J.; Hrevušová, Z. Species development of meadow stand related to yield. Grassl. Sci. Eur. 2009, 14, 265-268.

22. Raus, J.; Knot, P.; Hrabě, F. Effect of fertilization and harvest frequency on floristic composition and yields of meadow stand. Acta Univ. Agric. Silvic. Mendel. Brun. 2012, 60, 181-186. [CrossRef]

23. Elsaesser, M.; Kunz, H.G.; Briemle, G. Strategy of organic fertilizer use on permanent grassland results of a 22-year-old experiment on meadow and mowing-pasture. Grassl. Sci. Eur. 2008, 13, 580582. 
24. Søegaard, K.; Eriksen, J.; Askegaard, M. Herbs in grasslands - effect of slurry and grazing/cutting on species composition. Grassl. Sci. Eur. 2008, 13, 200-202.

25. Gruber, L.; Schauer, A.; Häusler, J.; Urdl, M.; Adelwöhrer, A.; Südekum, K.H. Influence of growth stage of permanent grassland on dry matter yield, nutritive value, feed intake and milk yield of dairy cows during the whole period of vegetation. Grassl. Sci. Eur. 2011, 16, 136-138.

26. Parsons, A.; Rowarth, J.; Thornley, J.; Newton, P.; Lemaire, G.; Hodgson, J.; Chabbi, A. Primary production of grasslands, herbage accumulation and use, and impacts of climate change. In: Lemaire, G.; Hodgson, J.; Chabbi, A., Eds, Grassland productivity and ecosystem services, 2011, CABI, Wallingford. 27. Jong-Won, R.; Jacob, H. The effect of cattle slurry on the forage yield and grassland ecosystem. J. Korean Soc. Grassl. Sci. 1997, 17, 35-42.

28. Müller, C.; Laughlin, R.J.; Christie, P.; Watson, C.J. Effects of repeated fertilizer and cattle slurry applications over 38 years on $\mathrm{N}$ dynamics in a temperate grassland soil. Soil Biol. Biochem. 2011, 43, 1362-1371. [CrossRef]

29. Komárek, P.; Kohoutek, A.; Fiala, J.; Odstrčilová, V.; Nerušil, P. Production and quality of grassland forage in dependence on cattle load and cutting frequency. In Kohoutek A., Pozdíšek J., Eds, Kvalita píce z travních porostů, 2005, VÚRV, v.v.i., Praha-Ruzyně, 175-182.

30. Szewczyk, W.; Kasperczyk, M.; Kacorzyk, P. Role of farmyard manure on upland meadows. Grassl. Sci. Eur. 2004, 9, 714-716.

31. Valkó, O.; Török, P.; Matus, G.; Tothmeresz, B. Is regular mowing the most appropriate and costeffective management maintaining diversity and biomass of target forbs in mountain hay meadows? Flora. 2012, 207, 303-309. [CrossRef]

32. Kramberger, B.; Gselman, A.; Podvršnik, M.; Lešnik, M.; Škorjanc, D. Effects of low precipitation periods on the herbage yield of mesic semi-natural grasslands under different cutting regimes. Zemdirbyste-Agricultur. 2014, 101, 11-18.

33. Criste, D.; Mihai, G.; Sima, N.; Medrea, I.; Botis, A.; Sima, R. Studies regarding the influence of organic and mineral fertilization on the permanent grassland from Maramures depression - Petrova. Bulletin UASVM Animal Science and Biotechnologies. 2013, 70, 240-243.

34. Vintu, V.; Samuil, C.; Trofin, A.; Popovici, I.C. The influence of organic and mineral fertilizers on fodder quality in NE Romania. Grassl. Sci. Eur. 2008, 13, 637-639.

35. Cabrera, M.L.; Gordillo, R.M. Nitrogen release from land-applied animal manures. In Hatcher K.J., Ed, Proceedings of the 1995 Georgia Water Resources Conference, 1995, University of Georgia, Athens. 